\title{
Knowledge management and entrepreneurship
}

Check for updates

\section{David B. Audretsch ${ }^{1} \cdot$ Maksim Belitski $^{2}$ (D) Rosa Caiazza $^{3} \cdot$ Erik E. Lehmann $^{4}$}

Published online: 3 March 2020

(C) The Author(s) 2020

\begin{abstract}
While research on knowledge management in entrepreneurial organizations has been the subject of much scholarly attention, it has mostly been considered independently rather than in institutional, geographical or industrial contexts. The purpose of this special issue is to integrate the role of context with knowledge management research, and to discuss the subsequent implications for entrepreneurship. This paper draws on the knowledge spillover theory of entrepreneurship, open innovation theory and the institutional perspective to knowledge management in entrepreneurial organizations, It does so in order to measure returns to investment in knowledge and knowledge spillovers across various industries and levels of economic activity (individual, firm, industry, university, region). Future research suggestions from the papers included in the special journal issue are also discussed and explained.
\end{abstract}

Keywords Entrepreneurship · Knowledge management · Context · Knowledge spillover · Knowledge collaboration

JEL Classification L25, L26 · L53

\section{Introduction}

The complexity of global change in knowledge management highlights the necessity of collaborative engagement between different fields of science. Researchers and

\author{
Maksim Belitski \\ m.belitski@ reading.ac.uk \\ David B. Audretsch \\ daudrets@indiana.edu \\ Rosa Caiazza \\ rosa.caiazza@uniparthenope.it
}

Erik E. Lehmann

erik.lehmann@wiwi.uni-augsburg.de

Extended author information available on the last page of the article 
practitioners are keen to strengthen our understanding of challenges related to investment in knowledge and technology internally, as well as our understanding of how to access knowledge via collaboration with external partners and knowledge spillover within domestic and across international contexts (Welter et al. 2019). Much of what is known about knowledge management in entrepreneurial organizations is based on studies of endogenous growth (Romer 1994), strategic entrepreneurship (Agarwal et al. 2010; Audretsch et al. 2015a; Ghio et al. 2015); international business and knowledge spillover of entrepreneurship (Cuervo et al. 2007; Acs et al. 2013) and open innovation theory (West et al. 2014; West and Bogers 2014).

In addition, the adoption of digital technologies has further changed the internal landscape of knowledge exploration and exploitation (Li et al. 2016). Spillovers have also changed the entrepreneurial environment for SMEs and scale-ups (McKelvie and Wiklund 2010; Hoffman and Yeh 2018; Kuratko et al. 2020). Comparatively little research has investigated channels of knowledge management within entrepreneurial organizations (Cohen and Levinthal 1989; Aizpurúa et al. 2011), across industries (Kenney and Patton 2005; Ratten 2011), within localized networks and clusters (Florida and Kenney 1988; Audretsch and Feldman 1996) or within international collaboration settings and contexts (Duysters and Lokshin 2011; Fernandes et al. 2013; Audretsch et al. 2015a).

Research on knowledge management in organizations overlaps with knowledge creation internally, the co-creation of knowledge with external partners (e.g. suppliers, customers, enterprise group, universities) (West and Bogers 2014) and outsourcing knowledge creation to collaborators. This has its own pros and cons (Ritala et al. 2015) which have been the subject of much scholarly attention.

Knowledge has become a conduit to entrepreneurs as a vehicle for adopting incoming knowledge spillovers (Cassiman and Veugelers 2002). It also allows new knowledge to spill over within and between industries (Tavassoli et al. 2017), leading to regional economic development and dynamism (Hayter 2013; Audretsch et al. 2015b; Caiazza et al. 2015).

The knowledge spillover theory of entrepreneurship (KSTE) builds on the endogenous growth theory (Romer 1994) and incorporates the role of entrepreneurs in the knowledge creation and commercialization process (Audretsch et al. 2006). It draws our attention to the context where knowledge creation and transfer takes place, and also to the role of the "knowledge filter" as an impediment to entrepreneurial activity (Audretsch and Keilbach 2007). Contrary to endogenous growth theories, the KSTE considers firm creation as an endogenous process in response to the availability of unused knowledge (Audretsch et al. 2006).

The KSTE perspective is crucial in understanding how knowledge collaboration and knowledge spillovers interact to identify and adopt new knowledge, while internal and external sources of knowledge have long been considered independently (Hall et al. 2009, 2013; Cassiman and Valentini 2016) rather than in combination with the strategic management of knowledge (Ferreira et al. 2017) and the KSTE (Acs et al. 2013). This special issue collects papers that draw on the knowledge spillover of entrepreneurship (e.g. external partners, in-house or collaborative R\&D activity, other investment in creative work, sourcing of labor, knowledge collaboration) in order to integrate these two strands of literature (Audretsch et al. 2005; Belitski 2019).

Consequently, this special issue contributes to the debate on knowledge frontiers and boundaries for entrepreneurial organizations (Belitski et al. 2019a, b) as well as 
knowledge exploration and exploitation (Kirzner 1999), and yields a new conceptual understanding of knowledge measurement and management (Powell and Grodal 2005) and its use by entrepreneurs (Caiazza et al. 2019). Manuscripts accepted for publication improve our understanding of the regional and international institutional challenges of knowledge creation, industry specificities and the management of knowledge across individual-team-firm-industry levels, along with knowledge spillover and knowledge commercialization within and across local, regional and national boundaries. They can also be of interest for practitioners and policymakers designing innovation and industrial policies in Europe and internationally.

\section{Investigating the knowledge management - entrepreneurship link}

Entrepreneurship activity relies on new and existing knowledge to facilitate economic development (Welter et al. 2019). While certain theories and empirical findings for entrepreneurship may hold in certain national and institutional contexts and not in others, the knowledge spillover theory of entrepreneurship (KSTE) holds across a variety of institutional and industry contexts and for developed and developing countries (Bruton et al. 2008; Agarwal et al. 2010; Audretsch and Belitski 2013).

KSTE explains how entrepreneurs use information and why the investment in firm's own knowledge should not undermine an entrepreneur's collaboration on knowledge with external partners (West and Bogers 2014; Roper et al. 2017) and access knowledge spillovers (Audretsch and Keilbach 2007; Hall and Sena 2017). In the new digital economy (Obschonka and Audretsch 2019) with greater openness and speed of information accumulation and exchange, underinvestment in knowledge is particularly troublesome. It can hinder survival, productivity and innovation, reducing opportunities for new knowledge capitalization by firms.

Theoretical and empirical evidence of knowledge management in organizations suggests that knowledge creation may take place internally or via knowledge spillovers. Investment in internal knowledge is required to facilitate innovation and productivity (Hall et al. 2009; Demircioglu et al. 2019), and in doing so firms will accumulate human capital and reach the critical mass of ideas needed to support entrepreneurial entry. Investment in knowledge collaboration and spillovers may bring knowledge from other industries that are not directly integrated into firm capabilities (Mowery 2009), but may be relevant for Schumpeterian-type innovation (Schumpeter 1942). One of the main challenges for firms and enterprise groups, however, remains the management of internal investment in knowledge, knowledge collaboration (Beers and Zand 2014) and knowledge spillovers altogether. This is an issue in particular for entrepreneurs who perform under rigid resource constraints (Cassiman and Veugelers 2002, 2006; Link and Scott 2019).

To unpack the set of direct and indirect inter-dependences between knowledge creation, commercialization and appropriation (Hall and Sena 2017), the industry context may be the most appropriate to use with studies in this special issue investigating knowledge management in the information technology sector (Khalil and Khalil 2020), the defense sector (Briones-Peñalver et al. 2020), healthcare (Islam et al. 2020), the semiconductor sector (Anzenbacher and Wagner 2020), the educational sector (Civera et al. 2020; Hahn 2020), the high-tech manufacturing sector (Tsvetkova et al. 2020) and a number of others. 
While knowledge management has often been researched on its own, researchers drew more attention on inter-connectedness and complementarities between internal knowledge and external knowledge sourcing (Link and Scott 2019), as well as the role of knowledge spillovers (West and Bogers 2014; Audretsch and Belitski 2019; Feldman and Audretsch 1999). First, knowledge management in organizations, regions and countries requires understanding the relationship between internal investment in $\mathrm{R} \& \mathrm{D}$ and external knowledge sourcing within the knowledge collaboration - spillover link. Each element in the above schematic has been studied individually by numerous scholars; however, there is a void in the economics of innovation and knowledge management literature about how different sources of knowledge can become complementary for entrepreneurship, innovation and productivity (Hall et al. 2013).

Second, knowledge management in organizations, regions and countries calls for an analysis of the decision-making process, with managers deciding on whether to make, buy or ally on knowledge creation, unlike the traditional sequential decision-making model (Crépon et al. 1998; Hall 2011).

This simultaneous approach to knowledge management reveals that decisions to invest in knowledge, collaborate on knowledge externally, receive it via spillovers, or even buy or imitate external knowledge are often taken simultaneously and are endogeneous as they often change. The simultaneous decision-making can be operationalized by solving a hierarchical model or a system of equations where the residuals (unobserved factors) will be highly interdependent. In doing so, research on knowledge management in organizations can bypass some of these measurement difficulties and the issues of endogeneity when dealing with knowledge inputs and outputs (Arora and Athreye 2012; Giovannetti and Piga 2017).

Thirdly, research on knowledge management requires the specification of costs and benefits from knowledge creation internally and via knowledge spillovers as an investment problem in which the expected outcome, such as innovation or entrepreneurship, can be maximized. The propensity of firms to innovate and enter new markets increases with their investment in internal knowledge (e.g. R\&D, training, advanced machinery and software investments) and the availability of knowledge spillovers (Acs et al. 2013; Link et al. 2007). Further knowledge spillovers facilitate innovation and market entry (Agarwal et al. 2010) as the number of knowledge connections increases, reaching a critical concentration of knowledge within a certain spatial or industrial unit (Audretsch and Feldman 1996; Balland et al. 2015). The expected pay-off from the knowledge spillovers and internal investment in knowledge is due to complementarities and an ability to quickly accumulate knowledge as well as the cognitive proximity between a source and recipient of knowledge.

Finally, knowledge collaboration and knowledge spillovers help firms to increase their economic value added and boost their competitiveness by integrating, modifying and creating new combinations of resources with those of other partners (Miotti and Sachwald 2003; Roper et al. 2017).

\section{Knowledge management and entrepreneurship in the digital age}

Recent knowledge management research pays significant attention to knowledge spillovers emerging from the use of big data, key enabling technologies (KET) (Carree et al. 
2019) and information and communications technologies (ICT) (Li et al. 2016; Khalil and Belitski 2020). The KSTE stands as a relevant theory/model addressing complementarities between internal investment in knowledge and knowledge spillovers originating from investment in technology and big data (Obschonka and Audretsch 2019). The extant theoretical and empirical research is focused on the role that technology plays in market opportunity identification and how in-house knowledge investment and knowledge sourcing from external partners should be aligned and coordinated.

First, the notion of strategic alignment builds on the arguments that investment in technology and KETs increases firm productivity, and also changes a firm's structures and capabilities to support the successful commercialization of new ideas. Second, alignment is a two-way process where internal knowledge investment in technology and knowledge spillovers (Roper et al. 2017) act as mutual drivers of informationbased knowledge and new opportunities identification (Qian et al. 2012). Third, the strategic alignment of technology and knowledge within a firm further improves its absorptive capacity (Cohen and Levinthal 1989; Mowery 2009) to continuous adaptation and change in an institutional context (Audretsch et al. 2019).

Higher internal investment in technology becomes a conduit for incoming knowledge spillovers (Cassiman and Veugelers 2006) to entrepreneurial activity, thus accelerating the magnitude of knowledge spillover emanating from entrepreneurial firms. It is reasonable to assume that technology and $R \& D$ investment may provide greater returns to knowledge spillovers, as a high absorptive capacity is required to recognize, adopt, combine and assimilate external knowledge. The relevance of technological advantages when using spillovers is due to difficulties in adopting knowledge spillover without specific training and ex-ante knowledge.

In a digital age the focus on retaining and accessing external knowledge via spillovers needs to be integrated into internal innovation practices and to be associated with the balancing of internal and external knowledge investment (Enkel et al. 2009).

Investment in knowledge is subject to decreasing marginal returns, other factors ceteris paribus, hence knowledge spillovers are seen as a facilitating mechanism shifting the technology-innovation sales curve upwards. While firms may rely on investment in R\&D and technology to maintain their absorptive capacities and facilitate knowledge spillovers, the following challenges will arise which may affect entrepreneurial decision-making about knowledge management and the use of spillovers.

First, there is an uncertainty in combining both internal knowledge and spillovers for the creation of new market opportunities: a manager will generally be uncertain about the distribution and yield of potential innovation outcomes and how these outcomes are transformed into market opportunities. Second, this distribution of payoffs from investment in internal knowledge (R\&D, ICT) and knowledge transfer via spillovers will be unequal. Third, the ability to substitute internal and external knowledge while innovating depends on the firm's absorptive capacity (Cohen and Levinthal 1989) as well as the firm's location relative to the production possibility frontier (Mickiewicz et al. 2017).

A firm will limit investment in own knowledge if the increase in the marginal cost of knowledge investment will be greater than the returns from spillovers. Meanwhile, the increasing market commercialization of knowledge entrepreneurs will inevitably face diminishing returns to the scale of internal knowledge investment. We therefore argue that with simultaneous investment in internal knowledge and knowledge spillovers, firms aim to achieve rapid growth (Jansen and Roelofsen 2018; Josefy et al. 2015). 


\section{Special issue papers}

The articles selected for this special issue convey to various degrees the insights we have previously mentioned emphasizing the role of cognitive proximity for knowledge and the importance of the industry context (Welter et al. 2019).

The first paper, written by Rafal Drewniak and Robert Karaszewski entitled Diffusion of knowledge in strategic alliance: empirical evidence discusses the essence and exchange of knowledge between enterprises within the framework of strategic alliances. The paper aims to identify the relationships between specific features related to the obtaining and sharing knowledge, the specificity of cooperating enterprises, and the characteristics of an alliance. It provides evidence to suggest that the relationship between the size of enterprises participating in an alliance and a favorable evaluation of the acquisition and sharing of knowledge is closer than in the case of the duration of an alliance. It also demonstrates significant positive correlation between the implementation of innovations and the duration of an alliance.

The second paper entitled, Three pillars of Knowledge Management in SMEs: Evidence from Serbia, was written by Viktorija Petrov, Djordje Celic, Zorica Uzelac and Zoran Draskovic. This work examines the relationship between the three pillars of knowledge management in SMEs representing strategy, marketing and human resource management. The paper's results suggest that knowledge management in SMEs within developing and transitioning economies could be described via a second-order hierarchical model composed of strategy, marketing and human resource management pillars. The organizational pillars of strategy, marketing and human resource management mutually reinforce the combination of resources available in firms (Mickiewicz et al. 2017). As the development of each pillar is costly, complementarities between strategy, marketing and human resources need to be better matched to maximise the return to investment in knowledge.

The role of distinctive individuals in leading investment in knowledge and enhancing a firm's ability to assimilate knowledge spillovers and bring uncommercialized knowledge to market has received little attention (Roper et al. 2017). In this regard, the third paper titled Fostering the creation of academic spinoffs: Does the international mobility of the academic leader matter? written by Alice Civera, Davide Donina, Michele Meoli and Silvio Vismara brings forward the role of leader in the process of knowledge creation and commercialization. This study investigates the role of university leaders in fostering the creation of academic spinoffs. It particularly focuses on the impact of university leader's international mobility. The study evidences that the mobility of university leaders positively affects the rate of establishment of academic spinoffs. These positive externalities are larger in internationalized universities as well as in international-oriented regions.

The fourth paper, entitled How university organizational culture shapes the relationship between the value created by student entrepreneurs and their psychological well-being: A social identity perspective', was written by Davide Hahn. This work focuses on the psychological well-being of student entrepreneurs, a key career outcome for the individual entrepreneur. It uses social identity theory to hypothesize that three different dimensions of student entrepreneurs' value creation - for oneself, for customers, for society - contribute to their psychological well-being. However, it argues that the extent of such contributions depends on the university's involvement with 
academic entrepreneurship, a visible component of its organizational culture. The paper shows that a university's involvement with academic entrepreneurship diminishes the negative downsides of poor value creation for oneself and for customers. .

The fifth paper is Surviving in a high-tech manufacturing industry: The role of innovative environment and proximity to metropolitan industrial portfolio' by Alexandra Tsvetkova and Tessa Conroy Jean-Claude. It builds on recent developments in evolutionary economics combined with a more traditional spillovers perspective to conceptualize the regional knowledge environment as consisting of two components: the base and the radical knowledge. It explores how a cohort of U.S. computer and electronic manufacturing companies with different absorptive capacity levels were able to benefit from the different types of knowledge available regionally. The results suggest reinforcing the dynamics between proximity to the metropolitan industry mix and the metropolitan patenting intensity in promoting the survival of non-patenting companies. This paper draws the reader's attention to the complementarity between innovative environments and their proximity to metropolitan industrial areas with the diversity that can further spillover into new market opportunities (Audretsch et al. 2006).

The sixth paper, written by Aaquib Islam Weizi Li Kevin Johnson Priam Lauchande, is entitled How far has the integrated care come? Applying an asymmetric lens to interorganizational trust amongst health and social care organizations, it uses an asymmetric perspective that concentrates on factors that eventually lead to the loss of interorganizational trust in the context of the National Health Service and local government seeking to join up health and social care services. The paper explores trust and asymmetry factors that undermine collaborative attempts towards successful service integration amongst health and social care players. It contributes to a scholarly understanding of asymmetry in the public sector and the role of trust in overcoming divisions and facilitating joint-up services among health and care organizations.

By doing this, this work acknowledges the existence of complementarities between knowledge collaboration and trust as an institutional phenomenon. Further research may build on the development of distinct models, where trust may become a core factor $\mathrm{n}$ entrepreneurial decision-making on inter-organizational collaboration beyond the healthcare industry.

The seventh paper, written by Sabine Khalil, Carine Khalil, is entitled Exploring Knowledge Management in Agile Software Development Organizations. This reviews the related work on agile software development by focusing on and examining knowledge management initiatives in agile organizations, and develops a theoretical model of knowledge management in agile environments. The paper highlights the way knowledge management is embedded in agile practices, including continuous communication, iterative development, knowledge repositories and engineering practices. It also emphasizes the importance of knowledge management in Information Technology development organizations. The authors demonstrate how new technologies can influence a firm's ability to achieve growth and to create and sustain a competitive advantage. The work contributes to a growing literature that links information technology and knowledge management to develop viable new business models of knowledge management. While the role of R\&D and its contributions to innovation have been widely discussed in the literature (Veugelers and Schneider 2018), studies which unpack the role of agility and ICT jointly on how innovation and knowledge management affect productivity have been limited. 
The eighth paper, entitled The Role of Exploration and Exploitation for Innovation Success: Effects of Business Models on Organizational Ambidexterity in the Semiconductor Industry, is by Armin Anzenbacher Marcus Wagner. It investigates the degree to which the need to balance exploration and exploitation for innovation depends on the business models pursued by firms in the global semiconductor industry. This is integrated with an assessment of the relative relevance of these internal knowledge sourcing mechanisms in comparison to mechanisms facilitating external knowledge spillovers, namely alliances and acquisitions. The research finds that the positive effect of internal knowledge management on innovation success is moderated by the business models pursued. This study highlights a significant limitation to the use of knowledge, which is a firm's ability to combine the exploration and exploitation of knowledge (Organizational Ambidexterity), as this may be costly and the outcomes uncertain. This leads us to consider that the exploration and exploitation of knowledge may be two substitutes for innovation strategy, but the mechanism is unclear.

The purpose of the ninth paper, Knowledge and Innovation Management Model. Its influence on Technology Transfer and Performance in Spanish Defense Industry, written by Antonio Juan Briones-Peñalver, Juan Andrés Bernal-Conesa Carmen de Nieves-Nieto is to analyze the influence of knowledge and innovation management on technology transfers and project performance. The results show that strategic alliances favor knowledge and innovation management. This knowledge and innovation management model has a positive influence on the technology transfer which helps project management to improve company performance.

Further research in this direction may focus on the ability of alliances to create and benefit from knowledge spillovers and knowledge collaboration and boost returns on investment in internal knowledge and knowledge transfer by alliances.

Finally, Maksim Belitski, Rosa Caiazza and Yulia Rodionova's paper on Investment in Training and Skills For Innovation Within Entrepreneurial Start-ups firms and Incumbents: Evidence from the United Kingdom extends the understanding of returns to knowledge investment by focusing on innovative training and skills in entrepreneurial firms and the role of patenting as an inducement for training in-house. This work theoretically and empirically extends Giovannetti and Piga (2017), who estimated returns to innovative training and $\mathrm{R} \& \mathrm{D}$ by demonstrating that training premiums are positive for innovation performance and that returns to investment training vary between firms of different size. Building on knowledge management in the organizations and innovation literature, this study advances our understanding of the knowledge investment and knowledge appropriation strategies used by entrepreneurial firms, as well as the role of knowledge investment in further inducement of R\&D, adding to Arora and Athreye's (2012) and Arora's et al. (2016) findings.

\section{Conclusions and future research}

In the papers discussed above, entrepreneurial activity is examined in the context of regions, industries and technologies. The previous literature examined the role that a firm's own knowledge and technology investment, as well as knowledge spillovers, play in enabling the exploration of knowledge frontiers and the expansion of knowledge boundaries. 
Based on a mix of perspectives (institutional, resource-based view, organizational synergies, knowledge management, innovation, KSTE), as well as the context of entrepreneurial decision-making, the papers in this special issue have examined the following topics: the subject of knowledge management and innovation in firms; the role of absorptive capacity in the exploration and exploitation of new knowledge; trust and inter-organizational collaboration; academic entrepreneurship and leadership; knowledge and well-being in universities; innovative training and sales of new-tomarket products; knowledge management in agile environments; and the role of the base and radical knowledge in firm survival. Our ambitious agenda is to investigate the role that internal investment plays in knowledge, R\&D and technology as well as the availability of knowledge spillovers and knowledge collaboration for identifying and commercializing market opportunities.

On the one hand, the selection of papers demonstrates how knowledge emanating from entrepreneurial firms and incumbents can become a source of knowledge spillover within each specific context of organization, alliance, industry or region. On the other hand, a selection of papers also suggested that knowledge spillovers, knowledge collaboration and firm's own R\&D investment may become powerful internal sources of knowledge and market innovation.

Overall, this special issue advances entrepreneurship research by expanding perspectives on knowledge management in organizations of different types in both Europe and the United States, and across a wide spectrum of industries that all benefit from the knowledge spillover of entrepreneurship. The papers made theoretical inroads by integrating a mix of theories and operationalizing the elements of these theories to examine the links between internal knowledge investment and technology as well as external knowledge sourcing via R\&D collaboration and spillovers in specific environmental contexts. Their findings are diverse and sometimes unexpected, demonstrating the complexity of the relationships between knowledge management and entrepreneurial activity that do not exist in a vacuum, but are affected by institutional quality, competitive industry conditions, resource limitations and complementarities between distinctive elements of external and internal organizational knowledge. Moreover, the papers in this special issue demonstrated the importance of aligning multiple elements within the same level of analysis (organizational level, skill composition, industry alignment and competition; university entrepreneurial ecosystems, regional innovation ecosystems, firm agility and resilience, and the use of KETs and information technologies).

The body of current knowledge in the literature calls for greater theoretical and empirical research to illuminate the relationship between complementarities between internal knowledge investment and knowledge spillovers. In particular across different levels of analysis (university, firms, industry, industry-regions; regional ecosystems and firm-alliances).

In particular, we call for subsequent studies to investigate knowledge managemententrepreneurship with a cross-country and cross-industry focus. They should especially focus on capturing the intensity of knowledge transfer and other emerging technologies which have advanced the innovation and entrepreneurship landscape into the digital age. Research into entrepreneurial organizations would benefit from further investigation into the role that R\&D investment and knowledge spillovers play in firm and regional productivity, with very little to no evidence incorporated in innovation- 
productivity models and exploring the tool of simultaneous equations and hierarchical models in addressing endogeneity between knowledge investment and firm (regional) performance. The papers in this special issue extend the knowledge frontiers and open new avenues for future research to investigate entrepreneurship as a heterogeneous multilevel phenomenon and knowledge as a conduit of entrepreneurship across multiple organizational functions, dimensions and levels.

Open Access This article is licensed under a Creative Commons Attribution 4.0 International License, which permits use, sharing, adaptation, distribution and reproduction in any medium or format, as long as you give appropriate credit to the original author(s) and the source, provide a link to the Creative Commons licence, and indicate if changes were made. The images or other third party material in this article are included in the article's Creative Commons licence, unless indicated otherwise in a credit line to the material. If material is not included in the article's Creative Commons licence and your intended use is not permitted by statutory regulation or exceeds the permitted use, you will need to obtain permission directly from the copyright holder. To view a copy of this licence, visit http://creativecommons.org/licenses/by/4.0/.

\section{References}

Acs, Z. J., Audretsch, D. B., \& Lehmann, E. E. (2013). The knowledge spillover theory of entrepreneurship. Small Business Economics, 41(4), 757-774.

Agarwal, R., Audretsch, D., \& Sarkar, M. B. (2010). Knowledge spillovers and strategic entrepreneurship. Strategic Entrepreneurship Journal, 4, 271-283.

Aizpurúa, L. I., Saldaña, P. E. Z., \& Saldaña, A. Z. (2011). Learning for sharing: An empirical analysis of organizational learning and knowledge sharing. International Entrepreneurship and Management Journal, 7(4), 509-518.

Anzenbacher, A. \& Wagner, M. (2020). The role of exploration and exploitation for innovation success: Effects of business models on organizational ambidexterity in the semiconductor industry. International entrepreneurship and management journal (this issue).

Arora, A., Athreye, S. (2012). Patent incentives: Returns to patenting and the inducement for research \& development. Intellectual property office research paper $(2012 / 20)$.

Arora, A., Athreye, S., \& Huang, C. (2016). The paradox of openness revisited: Collaborative innovation and patenting by UK innovators. Research Policy, 45(7), 1352-1361.

Audretsch, D. B., \& Feldman, M. P. (1996). R\&D spillovers and the geography of innovation and production. The American Economic Review, 86(3), 630-640.

Audretsch, D. B., Castrogiovanni, G. J., Ribeiro, D., \& Roig, S. (2005). Linking entrepreneurship and management: Welcome to the international entrepreneurship and management journal. International Entrepreneurship and Management Journal, 1(1), 5-7.

Audretsch, D. B., Keilbach, M. C., \& Lehmann, E. E. (2006). Entrepreneurship and economic growth. Oxford University Press.

Audretsch, D. B., \& Keilbach, M. (2007). The theory of knowledge spillover entrepreneurship. Journal of Management Studies, 44(7), 1242-1254.

Audretsch, D. B., \& Belitski, M. (2013). The missing pillar: the creativity theory of knowledge spillover entrepreneurship. Small Business Economics, 41(4), 819-836.

Audretsch, D. B., Kuratko, D. F., \& Link, A. N. (2015a). Making sense of the elusive paradigm of entrepreneurship. Small Business Economics, 45(4), 703-712.

Audretsch, D. B., Belitski, M., \& Desai, S. (2015b). Entrepreneurship and economic development in cities. The Annals of Regional Science, 55(1), 33-60.

Audretsch, D. B., Belitski, M., \& Desai, S. (2019). National business regulations and city entrepreneurship in Europe: A multilevel nested analysis. Entrepreneurship Theory and Practice, 43(6), 1148-1165.

Audretsch, D. B., \& Belitski, M. (2019). The limits to collaboration across four of the Most innovative UK industries. British Journal of Management. https://doi.org/10.1111/1467-8551.12353.

Balland, P. A., Boschma, R., \& Frenken, K. (2015). Proximity and innovation: From statics to dynamics. Regional Studies, 49(6), 907-920. 
Beers, C., \& Zand, F. (2014). R\&D cooperation, partner diversity, and innovation performance: An empirical analysis. Journal of Product Innovation Management, 31, 292-312.

Belitski, M., Caiazza, R., \& Lehmann, E. E. (2019a). Knowledge frontiers and boundaries in entrepreneurship research. Small Business Economics, 1-11.

Belitski, M., Aginskaja, A., \& Marozau, R. (2019b). Commercializing university research in transition economies: Technology transfer offices or direct industrial funding? Research Policy, 48(3), 601-615.

Belitski, M. (2019). Innovation in Schumpeterian-type firms: Knowledge collaboration or knowledge spillover? Foundations and Trends® in Entrepreneurship, 15(3-4), 368-390.

Briones-Peñalver, A.J., Bernal-Conesa, J.A. Nieves-Nieto, C. (2020). Knowledge and innovation management model. Its influence on technology transfer and performance in Spanish defense industry. International entrepreneurship and management journal (this issue).

Bruton, G. D., Ahlstrom, D., \& Obloj, K. (2008). Entrepreneurship in emerging economies: where are we today and where should the research go in the future. Entrepreneurship Theory and Practice, 32(1), 1-14.

Caiazza, R., Belitski, M., \& Audretsch, D. B. (2019). From latent to emergent entrepreneurship: the knowledge spillover construction circle. The Journal of Technology Transfer, 1-11.

Caiazza, R., Richardson, A., \& Audretsch, D. B. (2015). Knowledge effects on competitiveness: from firms to regional advantage. The Journal of Technology Transfer, 40(6), 899-909.

Carree, M., Lokshin, B., \& Alvarez, H. A. (2019). Technology partnership portfolios and firm innovation performance: Further evidence. Journal of Engineering and Technology Management, 54, 1-11.

Cassiman, B., \& Veugelers, R. (2002). R\&D cooperation and spillovers: Some empirical evidence from Belgium. American Economic Review, 92(4), 1169-1184.

Cassiman, B., \& Veugelers, R. (2006). In search of complementarity in innovation strategy: internal R\&D and external knowledge acquisition. Management Science, 52, 68-82.

Cassiman, B., \& Valentini, G. (2016). Open innovation: Are inbound and outbound knowledge flows really complementary? Strategic Management Journal, 37, 1034-1046.

Civera, A., Donina, D., Meoli, M., \& Vismara, S. (2020). Fostering the creation of academic spinoffs: does the international mobility of the academic leader matter? International Entrepreneurship and Management Journal, https://doi.org/10.1007/s11365-019-00559-8.

Cohen, W. M., \& Levinthal, D. A. (1989). Innovation and learning: the two faces of R\&D. The economic journal, 99(397), 569-596.

Crépon, B., Duguet, E., \& Mairessec, J. (1998). research, innovation and productivity: an econometric analysis at the firm level. Economics of Innovation and new Technology, 7(2), 115-158.

Cuervo, Á., Ribeiro, D., \& Roig, S. (2007). Entrepreneurship: concepts, theory and perspective. Introduction. In Entrepreneurship (pp. 1-20). Berlin, Heidelberg: Springer.

Demircioglu, M. A. (2019). David Audretsch: a great mind, an outstanding researcher, and a humble individual. In From industrial organization to entrepreneurship (pp. 439-442). Cham: Springer.

Duysters, G. M., \& Lokshin, B. (2011). Determinants of alliance portfolio complexity and its effect on innovative performance of companies. Journal of Product Innovation Management, 28(4), 570-585.

Enkel, E., Gassmann, O., \& Chesbrough, H. (2009). Open R\&D and open innovation: exploring the phenomenon. R\&D Management, 39(4), 311-316.

Feldman, M. P., \& Audretsch, D. B. (1999). Innovation in cities: science-based diversity, specialization and localized competition. European economic review, 43(2), 409-429.

Ferreira, J. J., Ratten, V., \& Dana, L. P. (2017). Knowledge spillover-based strategic entrepreneurship. International Entrepreneurship and Management Journal, 13(1), 161-167.

Fernandes, C., Ferreira, J., \& Raposo, M. (2013). Drivers to firm innovation and their effects on performance: an international comparison. International Entrepreneurship and Management Journal, 9(4), 557-580.

Florida, R. L., \& Kenney, M. (1988). Venture capital, high technology and regional development*. Regional Studies, 22(1), 33-48.

Ghio, N., Guerini, M., Lehmann, E. E., \& Rossi-Lamastra, C. (2015). The emergence of the knowledge spillover theory of entrepreneurship. Small Business Economics, 44(1), 1-18.

Giovannetti, E., \& Piga, C. A. (2017). The contrasting effects of active and passive cooperation on innovation and productivity: evidence from British local innovation networks. International Journal of Production Economics, 187, 102-112.

Hahn, D (2020). How university organizational culture shapes the relationship between the value created by student entrepreneurs and their psychological well-being: a social identity perspective. International Entrepreneurship and Management Journal (this issue).

Hall, B. (2011). Innovation and productivity, NBER working paper 17178.

Hall, B. H., Lotti, F., \& Mairesse, J. (2009). Innovation and productivity in SMEs: empirical evidence for Italy. Small Business Economics, 33, 13-33. 
Hall, B. H., Lotti, F., \& Mairesse, J. (2013). Evidence on the impact of R\&D and ICT investments on innovation and productivity in Italian firms. Economics of Innovation and New Technology, 22(3), 300328.

Hall, B. H., \& Sena, V. (2017). Appropriability mechanisms, innovation, and productivity: Evidence from the UK. Economics of Innovation and New Technology, 26(1-2), 42-62.

Hayter, C. S. (2013). Conceptualizing knowledge-based entrepreneurship networks: perspectives from the literature. Small Business Economics, 41(4), 899-911.

Hoffman, R., \& Yeh, C. (2018). Blitzscaling: the lightning fast path to building massively valuable companies. New York: Currency Books.

Islam, A., Li, W., Johnson, K., \& Lauchande, P. (2020). How far has the integrated care come? Applying an asymmetric lens to interorganisation trust amongst health and social care organization. International entrepreneurship and management journal (this issue).

Jansen, J.J.P., \& Roelofsen, O. (2018). Focus today on the growth of tomorrow'. Whitepaper. Nlgroeit, March 2018.

Josefy, M., Kuban, S., Ireland, R. D., \& Hitt, M. A. (2015). All things great and small: organizational size, boundaries of the firm, and a changing environment. The Academy of Management Annals, 9(1), 715802.

Kenney, M., \& Patton, D. (2005). Entrepreneurial geographies: support networks in three high-technology industries. Economic Geography, 81(2), 201-228.

Khalil, S. \& Khalil, C. (2020). Exploring knowledge Management in Agile Software Development Organizations. International entrepreneurship and management journal (this issue).

Khalil, S., \& Belitski, M. (2020). Dynamic capabilities for firm performance under the information technology governance framework. European Business Review ISSN: 0955-534X.

Kirzner, I. M. (1999). Creativity and/or alertness: A reconsideration of the Schumpeterian entrepreneur. The Review of Austrian Economics, 11(1-2), 5-17.

Kuratko, D. F., Holt, H. L., \& Neubert, E. (2020). Blitzscaling: the good, the bad, and the ugly. Business Horizons, 63(11), 109-119.

Li, W., Liu, K., Belitski, M., Ghobadian, A., \& O'Regan, N. (2016). E-leadership through strategic alignment: an empirical study of small-and medium-sized enterprises in the digital age. Journal of Information Technology, 31(2), 185-206.

Link, A. N., Siegel, D. S., \& Bozeman, B. (2017). An empirical analysis of the propensity of academics to engage in formal university technology transfer. In Universities and the Entrepreneurial Ecosystem. Cheltenham: Edward Elgar Publishing.

Link, A. N. \& Scott, J. T. (2019). The economic benefits of technology transfer from US federal laboratories. The Journal of Technology Transfer, 1-11.

McKelvie, A., \& Wiklund, J. (2010). Advancing firm growth research: a focus on growth mode instead of growth rate. Entrepreneurship Theory and Practice, 34(2), 261-288.

Mickiewicz, T., Nyakudya, F. W., Theodorakopoulos, N., \& Hart, M. (2017). Resource endowment and opportunity cost effects along the stages of entrepreneurship. Small Business Economics, 48(4), 953-976.

Miotti, L., \& Sachwald, F. (2003). Co-operative R\&D: Why and with whom?: an integrated framework of analysis. Research Policy, 32(8), 1481-1499.

Mowery, D. C. (2009). Plus ca change: Industrial R\&D in the third industrial revolution. Industrial and Corporate Change, 18(1), 1-50.

Obschonka, M., \& Audretsch, D. B. (2019). Artificial intelligence and big data in entrepreneurship: a new era has begun. Small Business Economics, 1-11.

Powell, W. W., \& Grodal, S. (2005). Networks of innovators. The Oxford handbook of innovation, 78.

Qian, H., Acs, Z. J., \& Stough, R. R. (2012). Regional systems of entrepreneurship: The nexus of human capital, knowledge and new firm formation. Journal of Economic Geography, 13(4), 559-587.

Ratten, V. (2011). Sport-based entrepreneurship: towards a new theory of entrepreneurship and sport management. International entrepreneurship and management journal, 7(1), 57-69.

Ritala, P., Olander, H., Michailova, S., \& Husted, K. (2015). Knowledge sharing, knowledge leaking and relative innovation performance: an empirical study. Technovation, 35, 22-31.

Romer, P. M. (1994). The origins of endogenous growth. The Journal of Economic Perspectives, 8(1), 3-22.

Roper, S., Love, J. H., \& Bonner, K. (2017). Firms' knowledge search and local knowledge externalities in innovation performance. Research Policy, 46(1), 43-56.

Schumpeter, J. A. (1942). Capitalism, socialism and democracy. New York: Harper.

Tavassoli, S., Bengtsson, L., \& Karlsson, C. (2017). Strategic entrepreneurship and knowledge spillovers: Spatial and aspatial perspectives. International Entrepreneurship and Management Journal, 13(1), 233249. 
Tsvetkova, A., Conroy, T., Thill, J-C. (2020). Surviving in a high-tech manufacturing industry: the role of innovative environment and proximity to metropolitan industrial portfolio. International Entrepreneurship and Management Journal (this issue).

Veugelers, R., \& Schneider, C. (2018). Which IP strategies do young highly innovative firms choose? Small Business Economics, 50(1), 113-129.

Welter, F., Baker, T., \& Wirsching, K. (2019). Three waves and counting: the rising tide of contextualization in entrepreneurship research. Small Business Economics, 52(2), 319-330.

West, J., \& Bogers, M. (2014). Leveraging external sources of innovation: A review of research on open innovation. Journal of Product Innovation Management, 31(4), 814-831.

West, J., Salter, A., Vanhaverbeke, W., \& Chesbrough, H. (2014). Open innovation: the next decade. Research Policy, 43(5), 805-811.

Publisher's note Springer Nature remains neutral with regard to jurisdictional claims in published maps and institutional affiliations.

\section{Affiliations}

\section{David B. Audretsch ${ }^{1} \cdot$ Maksim Belitski $^{2} \cdot$ Rosa Caiazza $^{3}$ - Erik E. Lehmann ${ }^{4}$}

1 School of Public and Environmental Analysis, Indiana University, Bloomington, 1315 E. Tenth St., Bloomington, IN 47405, USA

2 Henley Business School, University of Reading, Whiteknights, Reading RG6 6UD, UK

3 Parthenope University of Naples, Naples, Italy

4 Faculty of Business and Economics, University of Augsburg, Universitaetsstr. 16, 86159 Augsburg, Germany 